\title{
The role of B-cells in immunity against adult Strongyloides venezuelensis
}

\author{
Mohamed A EL-Malky ${ }^{1,2^{*}}$, Haruhiko Maruyama ${ }^{3}$, Saeed A Al-Harthi ${ }^{1}$, Samar N El-Beshbishi ${ }^{2}$ and Nobu Ohta ${ }^{4}$
}

\begin{abstract}
Background: Strongyloides venezuelensis has been used as a tool and model for strongyloidiasis research. Elimination of $S$. venezuelensis adult worms from mice has been particularly associated with proliferation and activation of intestinal mast cells and eosinophils. To date, the role of B-cells in the protective mechanism against adult Strongyloides infection in experimental animals has not been reported in the literature. Therefore, the present study was carried to investigate the role of B-lymphocytes in immunity against adult $\mathrm{S}$. venezuelensis infection using mice with a targeted deletion of the JH locus.
\end{abstract}

Methods: JHD knockout mice with its wild-type Balb/c mice were infected by intra-duodenal implantation of adult S. venezuelensis. Fecal egg count, intestinal worm recovery, mucosal mast cells and eosinophils were counted.

Results: At day 11 post infection, parasites in wild-type mice stopped egg laying, while in JHD knockout mice parasites continued to excrete eggs until the end of the observation period, day 107. The higher number of parasite eggs expelled in the feces of JHD knockout infected mice was a consequence of higher worm burdens, which established in the small intestine of these animals. On the other hand worm fecundity was comparable in both groups of mice. Both B-cell-deficient mice and wild-type mice, showed an influx of mucosal mast cells and eosinophils. The absolute numbers in JHD knockout mice were lower than those seen in wild-type mice at day 11 , but not to a level of significance. JHD knockout mice could not recover from infection despite the recruitment of both types of cells.

Conclusion: Our findings highlight a role of B cells in mucosal immunity against invasion of adult $\mathrm{S}$. venezuelensis and in its expulsion. Therefore, we conclude that B-cells together with mucosal mast cells and eosinophils, contribute to immunity against adult $S$. venezuelensis by mechanism(s) to be investigated.

Keywords: Strongyloides venezuelensis, B cells, JHD knockout, Immunity

\section{Background}

Nematode species that colonize the gastrointestinal tract represent a public health problem particularly in tropical and subtropical countries, and are responsible for millions of clinical cases and contributing to many deaths per year $[1,2]$. Among those, Strongyloides infection afflicts 30-100 million people in 70 different countries [3,4]. Accelerated auto-infection, mainly after an alteration in immune status, can cause a syndrome of severe hyperinfection or potentially fatal disseminated strongyloidiasis [5].

\footnotetext{
* Correspondence: mmelmalky@uqu.edu.sa

'Department of Medical Parasitology, Faculty of Medicine, Umm AL-Qura

University, Makkah, Kingdom of Saudia Arabia

${ }^{2}$ Department of Medical Parasitology, Faculty of Medicine, Mansoura

University, Mansoura, Egypt

Full list of author information is available at the end of the article
}

Despite the high prevalence and chronic morbidity produced by intestinal nematodes, immunoprotective mechanisms involved in the response against these parasites are not completely understood. Expulsion of parasites from host intestine is the most dramatic form of immunity in intestinal nematode infections [6]. Although the specific effector mechanisms involved in the control of primary nematode infection are not totally understood, type-2 immune responses, through the synthesis of IL-4, IL-5, IL-9 and IL-13, and consequent production of IgE, eosinophilia and mast cells, have been associated with host protection in many experimental models $[7,8]$. In the specific case of Strongyloides infection, the association of type- 2 immune response and protection of the host have been reported in human 
infection and in experimental models. S. venezuelensis has been used as a tool and model for strongyloidiasis research $[9,10]$. Elimination of $S$. venezuelensis adult worms from mice has been particularly associated with proliferation and activation of intestinal mast cells and eosinophils [11-15].

Several studies have demonstrated $>90 \%$ reduction in worm count and fecundity of worms in rats [16] and mice $[10,17,18]$ that were infected and challenged with live-larvae of $S$. venezuelensis or $S$. ratti compared to only primary infected animals. It has been suggested that eosinophils, neutrophils and parasite-reactive antibodies were associated with destruction of Strongyloides larvae [19-22].

The role of B-cells in primary and challenge infections of larval S. stercoralis in mice had been studied [21] and the authors concluded that B-cells are not required in the primary response, yet they are required in the secondary immune response.

To date, a detailed investigation of the role of B-cells in the protective mechanism against adult Strongyloides infection in experimental animals has not been reported in the literature. The use of the immunodeficient animals helps to understand the checkpoints in host immunity. Therefore, the present study was carried to investigate the role of B-lymphocytes in immunity against adult $S$. venezuelensis infection using mice with a targeted deletion of the $\mathrm{JH}$ locus. This phenotype results in the absence of B-cells and subsequently antibody production [23].

\section{Methods}

\section{Parasites and animals}

Male Balb/c mice and Wistar rats were purchased from Kyudo (Kumamoto, Japan). JHD knockout mice on a Balb/c background [23] have been purchased from Taconic (Hudson, NY, US).

S. venezuelensis has been maintained in male Wistar rats in the Division of Parasitology, Department of Infectious Diseases, University of Miyazaki, Japan [24]. Mice were infected by surgical implantation of adult $S$. venezuelensis worms in the small intestine. For adult worm implantation, the upper half of the small intestine of Wistar rats, 8-10 days post-infection was opened longitudinally and washed with phosphatebuffered saline (PBS), followed by incubation in PBS at $37^{\circ} \mathrm{C}$ for $80 \mathrm{~min}$. Adult worms that emerged from the intestine were washed with sterile PBS and adjusted to the appropriate number. Adult worms suspended in $500 \mu \mathrm{l}$ of PBS were inoculated into the duodenum of the ether-anesthetized mice (1500/mouse) [25]. All experimental animals were kept and handled under the guidelines of the Animal Experiment Committee, University of Miyazaki, Japan.

\section{Fecal egg count}

Feces were collected daily, starting 2 days after surgical implantation of S. venezuelensis worms. Individual feces were weighed separately, and suspended in water. Eggs in small portions of each sample were counted under a microscope, and the number of eggs per gram of feces (EPG) was determined for each sample [9].

\section{Recovery of adult worms from the intestine}

Worms were recovered at day 5 and 11 from the small intestine of each infected mouse according to the method described before [14]. Briefly, the upper half of the small intestine from each infected mouse was removed after sacrifice, washed, cut open longitudinally, and incubated in $\mathrm{PBS}$ at $37^{\circ} \mathrm{C}$ for $4 \mathrm{~h}$. Worms that emerged from the intestinal tissue were quantified by stereomicroscopy.

\section{Histology}

Mucosal mast cells and eosinophils were counted at the time of worm expulsion in wild type mice. For JHD knockout mice, a group of 5 mice were sacrificed for histological examination at day 11 (same day of wild type scarification), and the rest were sacrificed at the end of the observation period (day 107).

For mucosal mast cells, tissues of the small intestines were fixed with Carnoy's fixative, and paraffin-embedded

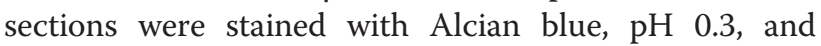
Safranin-O, pH 0.1 [26]. The number of intra-epithelial mast cells were counted in 50 villus-crypt units (VCU) and expressed as mast cell numbers per $10 \mathrm{VCU}$.

For eosinophils, tissues were fixed in acetone, and paraffin-embedded sections were stained with hematoxylin followed by $1 \%$ water soluble Biebrich Scarlet (Sigma) for $5 \mathrm{~min}$ [27]. The number of eosinophils in the small intestine was counted in $50 \mathrm{VCU}$ and expressed as eosinophil number per $10 \mathrm{VCU}$.

\section{Statistical analysis}

Experiments consisted of five mice per group and all experiments described were performed at least twice. SPSS software was used for data analysis. Descriptive statistics including the mean \pm standard deviation (SD), and median values were used. A non-parametric Mann-Whitney test was used to test for significant differences between groups. The data were considered significant if $P$ values were less than 0.05 .

\section{Results}

In this study, we surgically implanted adult worms to examine the mucosal protection against adult S. venezuelensis. After the same number of adult worms (1500/mouse) was implanted in the small intestine, both groups of mice started to lay eggs from the 2 nd day. The fecal egg count 


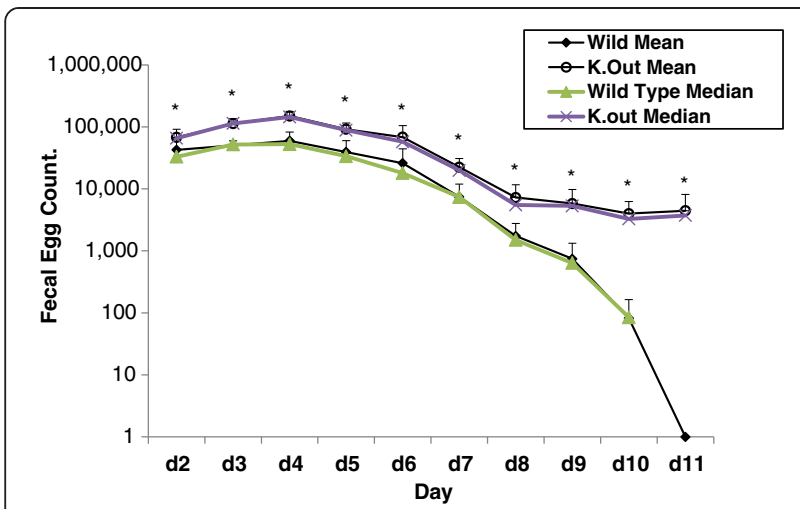

Figure 1 Fecal egg count after surgical implantation of S. venezuelensis adult worms in wild-type and JHD knockout mice. Mice were infected with 1500 adult worms, and EPG were counted from 2nd day after implantation. All values are mean $\pm S D$, and median values were also included. ${ }^{*} P<0.05$.

was significantly higher in JHD knockout mice compared to wild-type mice. Moreover, parasites from wild-type mice stopped laying eggs by day 11 after implantation, while parasites from JHD knockout mice continued to lay eggs till the end of the observation period, day 107 (Figure 1).

The kinetics of S. venezuelensis infection in mice revealed that there was a statistical difference in the numbers of worms recovered from the small intestines of knockout mice at day 5 after surgical implantation compared to wild type mice (Table 1). Worm fecundity was comparable in both groups of mice (Table 1). Day 11 post infection no worms were recovered from wild type mice.

At day 11, all wild type mice and one group of JHD knockout mice were sacrificed for histological examination. The number of mucosal mast cells (MMC) and eosinophils were comparable in both types of mice (Table 2).

By the end of the observation period (day 107), MMC and eosinophils in JHD knockout mice were still present,

Table 1 The number of worm recovery, fecal egg count and fecundity 5 days after surgical implantation of $S$. venezuelensis adult worms in wild-type and JHD knockout mice

\begin{tabular}{lcc}
\hline & Wild type mice & JHD knockout mice \\
\hline Worms recovered & $325 \pm 45$ & $749 \pm 50^{*}$ \\
& $(317)$ & $(747)$ \\
FEC & $39383 \pm 20397$ & $91896 \pm 23824^{*}$ \\
& $(33645)$ & $(88398)$ \\
Eggs/worm/gm feces & $117 \pm 47$ & $121 \pm 24$ \\
& $(106)$ & $(118)$
\end{tabular}

All values are mean \pm SD.

Numbers given between parentheses indicate the median value.

${ }^{*} P<0.05$.

FEC fecal egg count.
Table 2 The number of mucosal mast cells and eosinophils 11 days after surgical implantation of $S$. venezuelensis adult worms in wild-type and JHD knockout mice

\begin{tabular}{lcc}
\hline Cell count & Wild-type mice & JHD knockout mice \\
\hline MMC/10 VCU & $142 \pm 21$ & $123 \pm 15$ \\
Eosinophils/10 VCU & $(151)$ & $(120)$ \\
& $38 \pm 4$ & $34 \pm 3$ \\
\end{tabular}

All values are mean \pm SD.

Numbers given between parentheses indicate the median value. MMC mucosal mast cells.

VCU villus-crypt units.

with insignificantly lower counts compared to day 11 counts of the same group (Table 3).

\section{Discussion}

Despite the high prevalence and chronic morbidity produced by nematodes, immunoprotective mechanisms involved in the response against these parasites are not completely understood. In this study, we utilized mice with well-characterized mutations that disabled humoral immunity, in order to determine its role in host protection against adult $S$. venezuelensis.

In the absence of functional B-cells, JHD mice excreted significantly higher FEC compared to wild-type mice up to day 11 after infection. Parasites from wildtype mice stopped egg laying by day 11 , while parasites from JHD mice continued to excrete eggs till the end of the observation period, day 107. Although FEC is the only parasitological parameter of immunity that can be obtained sequentially and regularly in the same animal over the course of an infection, it does not strictly reflect the fecundity of the female worm population [28] as many other factors may affect the FEC. Determining the number of eggs in utero is a better index of decreased fecundity. Worm fecundity is determined by dividing the total eggs by the total number of adult worms recovered from the small intestine. Since S. venezuelensis-infected

Table 3 The number of mucosal mast cells and eosinophils in JHD knockout mice 11 and 107 days after surgical implantation of $S$. venezuelensis adult worms

\begin{tabular}{lcc}
\hline Cell count & $\begin{array}{c}\text { JHD knockout mice } \\
\text { Day 11 }\end{array}$ & $\begin{array}{c}\text { JHD knockout mice } \\
\text { Day 107 }\end{array}$ \\
\hline MMC/10 VCU & $123 \pm 15$ & $0.7 \pm 0.4^{*}$ \\
Eosinophils/10 VCU & $(120)$ & $(0.7)$ \\
& $34 \pm 3$ & $0.5 \pm 0.4^{*}$ \\
\hline
\end{tabular}

All values are mean $\pm \mathrm{SD}$.

Numbers given between parentheses indicate the median value.

*Significant difference vs. day $11(P<0.05)$.

$M M C$ mucosal mast cells.

VCU villus-crypt units. 
hosts have only female worms in the small intestine, worm fecundity can be estimated by dividing the number of eggs eliminated in feces by the number of worms recovered from the intestine of each mouse. At day 5 post infection, the kinetics of $S$. venezuelensis revealed that there was statistical difference in the numbers of worms that get established in the small intestines of knockout mice compared to wild type mice. At day 11 post infection, no worms were recovered from wild type mice indicating that all worms established had been expelled. From these data, it is clear that the higher number of parasite eggs excreted in the feces of JHD knockout infected mice was a consequence of higher worm burden in the small intestine of these animals. On the other hand worm fecundity was comparable in both groups of mice.

It is well known that in S. venezuelensis infection, mastocytosis and eosinophilia are associated with worm expulsion $[11,12,14,15]$. Worm expulsion was impaired in mice deficient in the IL-3 gene [11,29]. In these mice, MMC were completely absent and $S$. venezuelensis continued to parasitize the intestine for more than 50 days.

In the current study, both B-cell-deficient mice and wild-type mice, showed an influx of MMC and eosinophils. The absolute numbers in JHD knockout mice were lower than those seen in wild-type mice at day 11, but not to the level of significance.

JHD knockout mice could not recover from infection despite recruitment of both types of cells and their persistence until the end of the observation period. Therefore, it is clear that mucosal mastocytosis and eosinophilia are not solely responsible for worm expulsion and other effector mechanisms must be involved in the expulsion process. It is possible that the defect in worm expulsion following surgical implantation of adult $S$. venezuelensis results from the failure of mast cells and eosinophils to degranulate and release their effector mediators. We previously suggested a role of secretory IgA in conjugation with eosinophils in immunity against adult worm invasion and expulsion [14]. Furthermore, the role of IgE in mast cell degranulation remains equivocal; some authors claim IgE plays a role [30], while others deny any role for IgE [31]

To the best of our knowledge, we are the first to report a role for B cells in mucosal immunity against primary invasion of adult $S$. venezuelensis and in its expulsion. It appears that B cells play a critical role in the elimination of adult $S$. venezuelensis by antibodies or other mechanisms that remain to be fully investigated.

\section{Conclusion}

Our findings highlight a role of B cells in mucosal immunity against invasion of adult $\mathrm{S}$. venezuelensis and in its expulsion. Therefore, we conclude that B-cells together with mucosal mast cells and eosinophils, contribute to immunity against adult $\mathrm{S}$. venezuelensis by mechanism(s) to be investigated.

\section{Competing interests \\ The authors declare that they have no competing interests.}

\section{Authors' contributions}

ME, HM, SA and NO designed the experiment. ME, SA and SE performed lab work and drafted the manuscript. All authors read and approved the final version of the manuscript.

\section{Acknowledgement}

Mohamed EL-Malky was awarded a grant by the Short-term Invitation Program of Japan Student Services Organization (JASSO).

\section{Author details}

${ }^{1}$ Department of Medical Parasitology, Faculty of Medicine, Umm AL-Qura University, Makkah, Kingdom of Saudia Arabia. ${ }^{2}$ Department of Medical Parasitology, Faculty of Medicine, Mansoura University, Mansoura, Egypt. ${ }^{3}$ Division of Parasitology, Department of Infectious Diseases, Faculty of Medicine, University of Miyazaki, Miyazaki, Japan. ${ }^{4}$ Section of Environmental Parasitology, Graduate School of Medical and Dental Sciences, Tokyo Medical and Dental University, Tokyo, Japan.

Received: 14 February 2013 Accepted: 22 May 2013

Published: 24 May 2013

\section{References}

1. Chan MS: The global burden of intestinal nematode infections - 50 years on. Parasitol Today 1997, 13:438-443.

2. Crompton DWT: How much human helminthiasis is there in the world? J Parasitol 1999, 85:397-403.

3. Genta RM: Global prevalence of strongyloidiasis: critical review with epidemiologic insights into the prevention of disseminated disease. Rev Infect Dis 1989, 11:755-767.

4. Siddiqui AA, Berk SL: Strongyloidiasis. Curr Treatment Option 2003, 5:283-289.

5. Meamar AR, Rezaian M, Mohraz M, Hadighi R, Kia EB: Strongyloides stercoralis hyper-infection syndrome in HIV+/AIDS patients in Iran. Parasitol Res 2007, 101:663-665.

6. Wakelin D: Immunity to intestinal parasites. Nature 1978, 273:617-620.

7. Finkelman FD, Shea-Donohue T, Goldhill J, Sullivan CA, Morris SC, Madden KB, Gause WC, Urban JFJR: Cytokine regulation of host defense against parasitic gastrointestinal nematodes: lessons from studies with rodent models. Annu Rev Immunol 1997, 15:505-533.

8. Lawrence CE: Is there a common mechanism of gastrointestinal nematode expulsion. Parasite Immunol 2003, 25:271-281.

9. Sato Y, Toma H: Strongyloides venezuelensis infections in mice. Int J Parasitol 1990, 20:57-62

10. Sato $Y$, Toma H: Effects of spleen cells and serum on transfer of immunity to Strongyloides venezuelensis infection in hypothymic (nude) mice. Int J Parasitol 1990, 20:63-67.

11. Lantz CS, Boesiger J, Song CH, Mach N, Kobayashi T, Mulligan RC, Nawa Y, Dranoff G, Galli SJ: Role for interleukin-3 in mast-cell and basophil development and in immunity to parasites. Nature 1998, 392:90-93.

12. Fukao T, Yamada T, Tanabe M: Selective loss of gastrointestinal mast cells and impaired immunity in PI3K-deficient mice. Nat Immunol 2002, 3:295-304

13. Maruyama H, Yabu $Y$, Yoshida A, Nawa $Y$, Ohta N: A role of mast cell glycosaminoglycans for the immunological expulsion of intestinal nematode, Strongyloides venezuelensis. J Immunol 2000, 164:3749-3754.

14. El-Malky M, Maruyama H, Hirabayashi Y, Shimada S, Yoshida A, Amano T, Tominaga A, Takatsu K, Ohta N: Intraepithelial infiltration of eosinophils and their contribution to the elimination of adult intestinal nematode, Strongyloides venezuelensis in mice. Parasitol Int 2003, 52(1):71-79.

15. Sasaki Y, Yoshimoto T, Maruyama H, Tegoshi T, Ohta N, Naoki K, Arizono N, Nakanishi K: IL-18 with IL-2 protects against Strongyloides venezuelensis infection by activating mucosal mast cell-dependent type 2 innate immunity. J Exp Med 2005, 202:607-616.

16. Baek BK, Islam MK, Kim BS, Lim CW, Hur J, Oluoch AO, Kim C, Kakoma I: Characterization of the protective response against a homologous 
challenge infection with Strongyloides venezuelensis in rats. Vet Parasitol 2003, 113:217-227.

17. Grove DI, Northern C: Dissociation of the protective immune response in mouse to Strongyloides ratti. J Helminthol 1989, 63:307-314.

18. Watanabe K, Noda K, Hamano S, Koga M, Kishihara K, Nomoto K, Tada I: The crucial role of granulocytes in the early host defense against Strongyloides ratti infection in mice. Parasitol Res 2000, 86:188-193.

19. Rotman HL, Yutanawiboonchai W, Brigandi RA, Leon O, Gleich GJ, Nolan TJ, Schad GA, Abraham D: Strongyloides stercoralis: eosinophil-dependent immune-mediated killing of third stage larvae in BALB/cByJ mice. Exp Parasitol 1996, 82:267-278.

20. Herbert DR, Lee JJ, Lee NA, Nolan TJ, Schad GA, Abraham D: Role of IL-5in innate and adaptive immunity to larval Strongyloides stercoralis in mice. J Immunol 1989, 165:4244-4551.

21. Herbert DR, Nolan TJ, Schad GA, Abraham D: The role of B cells in immunity against larval Strongyloides stercoralis in mice. Parasite Immunol 2002, 24:95-101.

22. Galioto AM, Hess JA, Nolan TJ, Schad GA, Lee JJ, Abraham D: Role of eosinophils and neutrophils in innate and adaptive protective immunity to larval Strongyloides stercoralis in mice. Infect Immun 2006, 74:5730-5738.

23. Chen JM, Trounstine FW, Alt F, Young C, Kurahara JF, Loring D, Huszar D: Immunoglobulin gene rearrangement in B cell deficient mice generated by targeted deletion of the JH locus. Int Immunol 1993, 5:647-656.

24. Maruyama $\mathrm{H}$, Nawa Y, Ohta N: Strongyloides venezuelensis: binding of orally secreted adhesion substances to sulfated carbohydrates. Exp Parasitol 1998, 89:16-20.

25. Maruyama H, Hatano H, Kumagai T, El-Malky M, Yoshida A, Ohta N: Strongyloides venezuelensis: Heparin-binding adhesion substances inimmunologically damaged adult worms. Exp Parasitol 2000, 95:170-175

26. Abe T, Nawa Y: Reconstitution of mucosal mast cells in W/WV mice by adoptive transfer of bone marrow-derived cultured mast cells and its effects on the protective capacity to Stongyloides ratti infection. Parasite Immunol 1987, 9:31-38.

27. Konwalinka G, Glaser P, Odavic R, Bogusch E, Schmalzl F, Braunsteiner HA: New approach to the morphological and cytochemical evaluation of human bone marrow CFUC in agar cultures. Exp Hematol 1980, 8:434-440.

28. Claerebout $\mathrm{E}$, Vercruysse $\mathrm{J}$ : The immune response and the evaluation of acquired immunity against gastrointestinal nematodes in cattle. Parasitology 2000, 120(Suppl):S25-S42

29. Khan Al, Horii Y, Tiuria R, Sato Y, Nawa Y: Mucosal mast cells and the expulsive mechanisms of mice against Strongyloides venezuelensis. Int J Parasitol 1993, 3:551-555.

30. Dawkins HJS, Carroll SM, Grove DI: Humoral and cell-mediated immune responses in murine strongyloidiasis. Aust J Exp Biol Med Sci 1982, 60:717-729

31. Korenaga M, Nawa T, Tada I: IgE response in Strongyloide sratti-infected rats with special reference to life cycle of the parasite. Z Parasitenkd 1986, 72:213-220.

doi:10.1186/1756-3305-6-148

Cite this article as: EL-Malky et al:: The role of B-cells in immunity against adult Strongyloides venezuelensis. Parasites \& Vectors 2013 6:148.

\section{Submit your next manuscript to BioMed Central and take full advantage of:}

- Convenient online submission

- Thorough peer review

- No space constraints or color figure charges

- Immediate publication on acceptance

- Inclusion in PubMed, CAS, Scopus and Google Scholar

- Research which is freely available for redistribution 